\title{
Atribut Pemilihan Kualitas Restoran: Citra Merek dan Harga
}

Submitted Date :

26 Nopember 2019

Accepted Date :

2 Desember 2019

\author{
Echo Perdana Kusumah \\ Universitas Pendidikan Indonesia \\ echopk@upi.edu \\ Ratih Hurriyati \\ Universitas Pendidikan Indonesia \\ rhurriyati@upi.edu \\ Puspo Dewi Dirgantari \\ Universitas Pendidikan Indonesia \\ puspodewi@upi.edu
}

\section{Suggested Citation:}

Erkmen, E., \& Hancer, M. 2019. Building brand relationship for restaurants: An examination of other customers, brand image, trust, and restaurant attributes. International Journal of Contemporary Hospitality Management, 31(3), 1469-1487.

Abstract:

This research examines the impact of brand image and price on the preferences attributes of restaurants (service quality, food quality and atmosphere). Structural Equation Model (SEM) applied using 169 respondents as tourist and AMOS application tests the hypothesis. Results show that restaurant attribute preferences positively influenced by the brand image and price. Brand image does not affect significantly all restaurant quality attributes (service quality). Service quality does have a positive relationship to the brand image built by a restaurant, but not necessarily the level of service as desired by consumers, where consumers have different characters and perceptions in terms of being served. These studies also reveal that customer service or restaurant waiters attract new customers and maintain existing customers by improving their restaurant's food quality, service quality, and atmosphere.

Keyword: food prices; restaurant atmosphere; restaurant quality; service quality

\section{Abstrak:}

Studi ini meneliti dampak citra merek dan harga pada atribut preferensi restoran (kualitas layanan, kualitas makanan, dan suasana). Structural Equation Model (SEM) diterapkan dengan menggunakan 169 responden dan aplikasi AMOS untuk menguji hipotesis. Hasil menunjukkan bahwa preferensi atribut restoran secara positif dipengaruhi oleh citra merek dan harga. Citra merek tidak mempengaruhi secara signifikan semua atribut kualitas restoran (kualitas layanan). Kualitas layanan memang memiliki hubungan positif dengan citra merek yang dibangun oleh sebuah restoran, tetapi belum tentu tingkat layanan yang diinginkan oleh konsumen, di mana konsumen memiliki karakter dan persepsi yang berbeda dalam hal dilayani. Studi ini juga mengungkapkan bahwa pemilik restoran dapat menarik pelanggan baru dan mempertahankan pelanggan yang ada dengan meningkatkan kualitas makanan, kualitas layanan, dan suasana restoran mereka.

Kata Kunci: Harga makanan, Kualitas pelayanan, Kualitas restoran, Suasana restoran

JEL Classification: L83, L11, M31 


\section{Pendahuluan}

Bisnis restoran merupakan salah satu bisnis paling kompetitif di dunia, 33\% dari semua restoran tutup atau ubah kepemilikan dalam satu tahun dan 60\% di antaranya dalam 3 (tiga) tahun (White, 2011). Oleh karena itu, mengetahui karakteristik utama target pasar restoran (DiPietro \& Levitt, 2019) dan memutuskan faktor-faktor kompetitif mana yang dapat menarik konsumen baru (Reich, 2011) dan mempertahankan pelanggan yang sudah ada sangat penting untuk mengelola restoran yang sukses (Ding \& Chung, 2014). Selain itu, manajer atau operator restoran harus tahu apa yang membuat restoran mereka unik dan mengapa konsumen memilih restoran tertentu untuk pengalaman bersantap mereka (DeMicco, 2015). Mengingat karakteristik tidak berwujud dari produk restoran, konsumen sangat bergantung pada petunjuk nyata dan realistis untuk menilai produk sebelum mereka membelinya (Miao \& Mattila, 2013).

Dalam industri kuliner, harga dan citra merek dianggap sebagai indikator utama yang memengaruhi perilaku konsumen (Yi, Zhao, \& Joung, 2018). Secara tradisional, harga memainkan peran penting dalam memberikan petunjuk obyektif tentang kualitas produk dan layanan. Penelitian sebelumnya menemukan bahwa perilaku pembelian konsumen dipengaruhi oleh informasi harga (McCall \& Bruneau, 2010). Dalam riset ilmu ekonomi, harga dianggap sebagai faktor penting yang menentukan ekspektasi konsumen dan karenanya terdapat evaluasi pembelian oleh konsumen (Jongwanich, Park, \& Wongcharoen, 2019). Joung, Choi, \& Wang (2016) menyatakan bahwa harga adalah faktor penting dalam pembentukan evaluasi konsumen terhadap kualitas produk selama pengalaman bersantap mereka. Vuong \& Khanh-Giao (2019) juga menemukan bahwa harga produk secara positif mempengaruhi persepsi konsumen terhadap kualitas produk dan nilai pelanggan. Artinya, jika konsumen menganggap harga penawaran masuk akal, mereka cenderung lebih puas dengan pengalaman bersantap mereka.

Citra merek juga telah menjadi konsep penting dalam penelitian terkait restoran karena citra merek mempengaruhi persepsi subjektif konsumen, serta mempengaruhi niat, kepuasan, dan loyalitas pembelian (Jin, Lee, \& Pria, 2012). Citra merek secara positif memainkan peran penting dalam merangsang emosi positif pada konsumen tentang restoran, yang pada akhirnya menyebabkan kepuasan dan loyalitas konsumen (Lee, Back, \& Kim, 2009; Kusumah, 2018). Selain daripada itu, citra merek juga secara langsung mempengaruhi pengambilan keputusan konsumen, lebih dari nilai konsumen lainnya (misalnya: kualitas layanan) dalam pengaturan restoran (Hwang \& Ok, 2013). Jalilvand et al. (2016) juga menyarankan bahwa loyalitas pelanggan restoran sebanding dengan preferensi merek restoran. Dalam hal ini, membangun citra merek yang positif adalah strategi pemasaran yang penting di industri kuliner saat ini, untuk mempertahankan pelanggan yang sudah ada dan menarik konsumen yang baru.

Saat ini, dengan meningkatnya keinginan konsumen untuk memiliki pengalaman bersantap yang luar biasa, suasana restoran telah menjadi faktor signifikan dalam pengalaman konsumen restoran (Hyun, 2010; Dutta et al., 2014). Selain itu, suasana restoran sering memainkan peran penting dalam meningkatkan efek kualitas makanan dan layanan (Ryu \& Han, 2010; Bufquin, DiPietro, \& Partlow, 2017). Dalam literatur perhotelan, kualitas makanan merupakan faktor fundamental konsumen restoran yang ingin memiliki pengalaman puas dalam bersantap (Roseman, Mathe-Soulek, \& Krawczyk, 2017). Seperti kualitas makanan, kualitas layanan memainkan peran penting dalam kepuasan konsumen restoran. Kualitas layanan merupakan faktor yang sangat subyektif dan emosional dari kualitas restoran secara keseluruhan. Pelanggan menganggap keterampilan interpersonal karyawan restoran dalam melayani konsumen berkorelasi langsung dengan persepsi tentang seberapa baik layanan tersebut (Fan \& Shen, 2019). Misalnya, layanan impersonal sangat tidak menyenangkan sementara sikap yang hangat dari staf layanan membuat konsumen merasa sangat diterima, serta membuat mereka ingin menghargai staf untuk keramahan mereka. Selain itu, kualitas layanan tidak hanya mempengaruhi kepuasan konsumen tetapi juga kepercayaan konsumen, diikuti oleh loyalitas konsumen (Bowden-Everson, Dagger, \& Elliott, 2013; Cao \& Kim, 2015).

Berdasarkan penjelasan diatas, studi ini akan menyelidiki bagaimana citra merek dan harga mempengaruhi ketiga atribut pemilihan restoran yang diantaranya kualitas layanan, kualitas makanan, dan suasana. Oleh karena itu, tujuan dari penelitian ini adalah 1) untuk menguji pengaruh citra merek pada atribut pemilihan restoran, dan 2) 
untuk menguji pengaruh harga terhadap atribut pemilihan restoran. Studi ini dilaksanakan di Kota Pangkalpinang, Provinsi Kepulauan Bangka Belitung, Indonesia.

\section{Hipotesis}

Dalam arti tersempit, harga adalah jumlah uang yang dibebankan untuk suatu produk atau layanan. Lebih luas lagi, harga adalah jumlah dari semua nilai yang diberikan konsumen untuk mendapatkan manfaat memiliki atau menggunakan produk atau layanan (Kotler, Armstrong, \& Opresnik, 2017). Kualitas layanan restoran tidak dapat dievaluasi oleh konsumen sebelum ia memiliki pengalaman di restoran yang dituju, dan ketidakpastian ini membuat konsumen ragu-ragu dalam memilih pilihan kuliner. Namun, umumnya harga dapat memberikan petunjuk objektif tentang tingkat layanan atau produk. Dengan informasi harga tertentu, konsumen dapat dipengaruhi untuk mengubah perilaku pembeliannya (Kim, Lee, \& Mattila, 2014). Oleh karena itu, harga adalah salah satu indikator utama dalam memahami perilaku konsumen.

Selain itu, harga memiliki efek yang berarti pada ekspektasi nilai pelanggan dari sebuah restoran (Nemeschansky, 2019). Harga memainkan peran penting dalam membentuk ekspektasi konsumen akan kualitas. Artinya, semakin tinggi harga yang diamati oleh konsumen, semakin tinggi kualitas layanan yang diharapkan konsumen, karena harga yang lebih tinggi menambah nilai persepsi kualitas layanan (Wu \& Mohi, 2015). McCall \& Bruneau (2010) menunjukkan bahwa kualitas yang diharapkan dari sebuah restoran berbanding lurus dengan harga yang dirasakan. Harga memainkan peran positif dalam tingkat kepuasan konsumen dan preferensi pascapembelian untuk memilih restoran (Kim, Raab, \& Bergman, 2010). Menurut Ryu dan Han (2010), kualitas makanan adalah anteseden yang paling penting dari preferensi pilihan konsumen restoran, diikuti oleh suasana dan kualitas layanan. Hasil tersebut juga menunjukkan bahwa pengaruh harga tidak hanya preferensi atribut restoran oleh konsumen tetapi juga prioritas konsumen berdasarkan persepsi harga. Artinya, seiring kenaikan harga, konsumen menafsirkan ini sebagai peningkatan kualitas produk. Semakin tinggi harga, semakin tinggi kualitas yang dipersepsikan dan ekspektasi konsumen akan nilainya. Berdasarkan beberapa kajian diatas, maka hipotesis yang dibentuk sebagai berikut:

H1: Harga memiliki pengaruh yang positif terhadap preferensi suasana konsumen.

$\mathrm{H} 2$ : Harga memiliki pengaruh yang positif terhadap preferensi kualitas makanan konsumen.

H3: Harga memiliki pengaruh yang positif terhadap preferensi kualitas layanan konsumen.

Menurut Kotler, Armstrong, \& Opresnik (2017), citra merek tidak hanya membantu identifikasi produk secara umum tetapi juga membantu konsumen membedakan merek produk yang berbeda. Citra merek memainkan peran anteseden yang penting dalam hal persepsi konsumen terhadap kualitas produk, menunjukkan nilai produk dan dengan demikian mempengaruhi niat pembelian konsumen. Selain itu, citra merek yang mapan secara positif memengaruhi preferensi, kepercayaan, dan loyalitas pelanggan (Jin, Lee, \& Huffman, 2012; Jin, Line, \& Merkebu, 2016). Bowden-Everson, Dagger, \& Elliott (2013) menyatakan bahwa merek yang kuat menginspirasi kepercayaan pada pelanggan dan mengarah pada persepsi positif terhadap suatu produk. Kotler, Armstrong, \& Opresnik (2017) mendefinisikan kepercayaan sebagai variabel yang paling diterima secara universal sebagai dasar dari interaksi atau pertukaran manusia. Kepercayaan memainkan peran penting bagi konsumen dalam membangun citra merek suatu produk (Hyun, Han, \& Kim, 2016). Tingkat kepercayaan sebanding dengan tingkat citra merek (Ali et al., 2018). Oleh karena itu, citra merek memiliki efek langsung pada persepsi nilai konsumen, kepercayaan mereka, dan bahkan niat pembelian mereka.

Penelitian telah dilakukan dalam berbagai cara mengenai dampak merek pada persepsi konsumen. Sebagai contoh, loyalitas merek ditemukan memiliki dampak yang signifikan pada preferensi produk konsumen dan niat beli (Bruwer \& Buller, 2012). Citra merek yang mapan ditemukan menjadi faktor utama dalam loyalitas merek konsumen (Espinosa et al., 2018). Keakraban merek tidak hanya menunjukkan risiko yang lebih rendah dalam memilih produk (Wang, 2015) tetapi juga membangkitkan preferensi (Erkmen \& Hancer, 2019). Atas dasar hasil 
empiris yang diberikan, studi ini mengusulkan bahwa citra merek mempengaruhi preferensi atribut restoran konsumen ketika memilih restoran favorit mereka. Berdasarkan beberapa kajian diatas, maka hipotesis yang dibentuk sebagai berikut:

$\mathrm{H} 4$ : Citra merek memiliki pengaruh yang positif terhadap preferensi suasana konsumen.

H5: Citra merek memiliki pengaruh yang positif terhadap preferensi kualitas makanan konsumen.

H6: Citra merek memiliki pengaruh yang positif terhadap preferensi kualitas layanan konsumen.

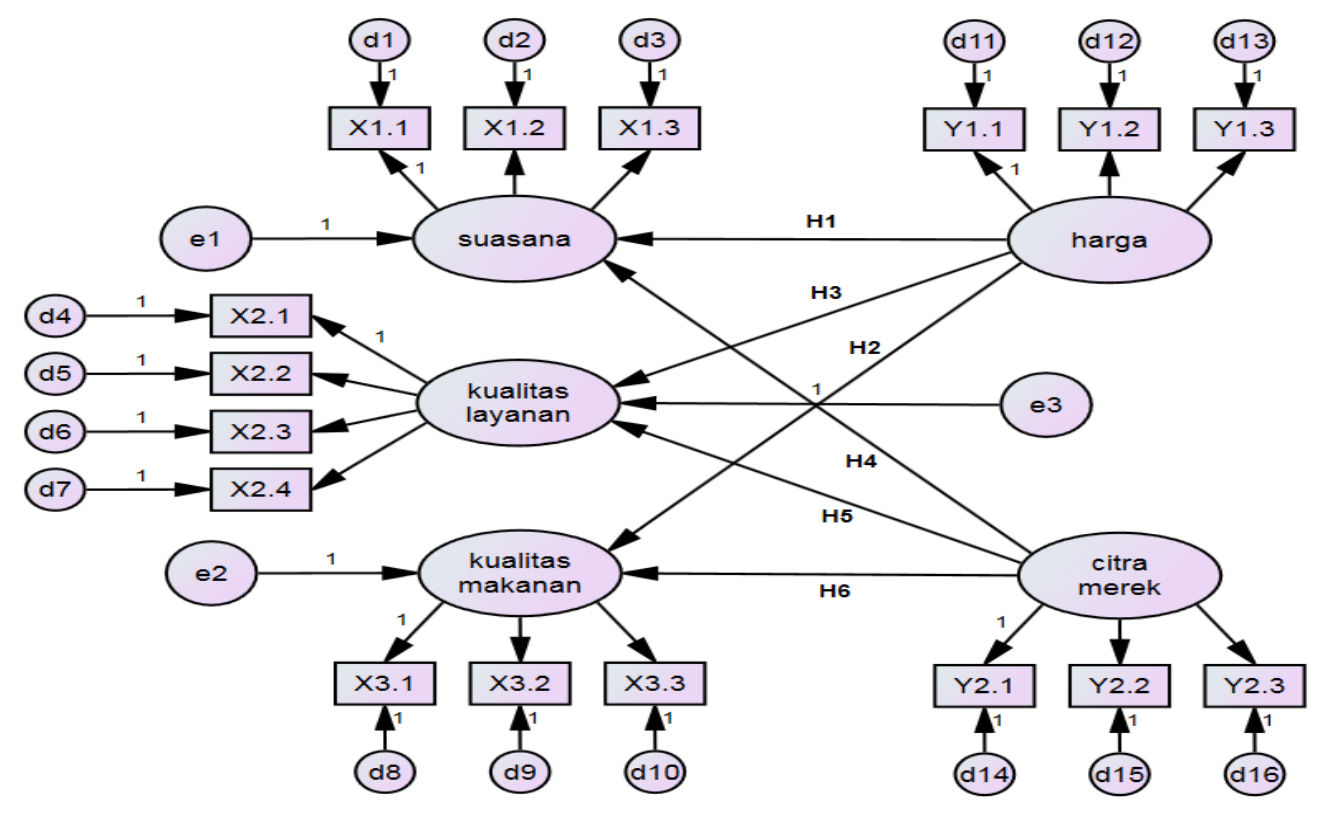

Gambar 1. Model Penelitian

\section{Metode Penelitian}

Kuesioner penelitian ini dikembangkan berdasarkan tinjauan hasil penelitian sebelumnya mengenai atribut yang relevan dengan pemilihan restoran (suasana, kualitas makanan, dan kualitas layanan) dan persepsi responden tentang harga dan citra merek restoran. Suasana restoran diukur dengan tiga item: interior, peralatan, dan kenyamanan (Hyun, 2010). Kualitas makanan diukur dengan tiga item: rasa, nutrisi, dan sanitasi (Choi \& Zhao, 2014). Kualitas layanan diukur dengan empat item: kecepatan, keramahan, keterampilan komunikasi, dan layanan profesional (Harrington et al., 2013). Harga diukur dengan tiga item: kesesuaian harga, kelengkapan harga, dan perlakuan harga (Kusumah, 2019). Persepsi citra merek diukur dengan tiga item: keterkenalan merek, brand recognition, dan kesan merek (Kusumah, 2018). Kuesioner menggunakan Skala Likert 5 poin mulai dari 1 (sangat tidak setuju) hingga 5 (sangat setuju). Kuesioner juga dilengkapi dengan informasi demografis seperti usia, jenis kelamin, tingkat pendidikan dan interest to come.

Sebelum pengumpulan data, kuesioner elektronik (google form) diberikan kepada para mahasiswa di Universitas Bangka Belitung yang berasal dari luar provinsi Kepulauan Bangka Belitung yang berjumlah 30 orang. Tujuannya adalah untuk menentukan apakah responden memahami dengan jelas item pengukuran, sehingga memastikan keandalan dan validitas pengukuran. Modifikasi dilakukan berdasarkan analisis komentar para mahasiswa tersebut. Teknik sampling yang digunakan adalah convenience sampling, dimana peneliti dapat mengurangi jawaban yang bias dari responden dan meningkatkan ketepatan pemilihan responden yang sesuai dengan studi ini (Hair et al., 2017). Survei dilaksanakan oleh para mahasiswa yang berjumlah 30 orang dan disebarkan terhadap wisatawan atau turis yang sedang mengunjungi beberapa restoran terkenal di Kota Pangkalpinang dalam kurun waktu 37 hari. Responden diberitahukan bahwa partisipasi mereka bersifat rahasia sehingga hasilnya akan tetap bersifat anonymous. Peneliti berharap mendapatkan jawaban dari responden berjumlah lebih dari 100 orang dalam waktu yang telah ditentukan. 
AMOS v.23 digunakan dalam menganalisis data yang mengikuti prosedur dua langkah yang disarankan oleh Hair et al. (2014). Pertama, analisis faktor konfirmatori (CFA) diterapkan untuk memverifikasi apakah konstruk pengukuran memenuhi persyaratan reliabilitas, validitas, dan unidimensional, karena atribut kualitas restoran memiliki cukup banyak item. Setelah CFA, permodelan persamaan struktural (SEM) dilakukan untuk menilai kecocokan model dari model yang diusulkan dan untuk menguji keterkaitan yang diusulkan antara harga, citra merek, kualitas makanan, kualitas layanan, dan suasana restoran. SPSS v.23 juga digunakan untuk mengolah data profil demografi responden.

\section{Hasil Penelitian}

Setelah dilakukan survei, didapatkan jumlah responden sebesar 201 orang. Seluruh responden berasal dari luar wilayah Provinsi Kepulauan Bangka Belitung dan dapat dikategorikan sebagai wisatawan nasional. Setelah pengumpulan data, ternyata ada beberapa kuesioner yang tidak lengkap dijawab oleh responden sehingga jumlah sampel yang digunakan berjumlah 169 responden untuk analisis lebih lanjut.

Tabel 1. Profil Demografi Responden

\begin{tabular}{|c|c|c|}
\hline Karakteristik & $\mathbf{N}$ & $\%$ \\
\hline \multicolumn{3}{|l|}{ Jenis Kelamin } \\
\hline Pria & 90 & 53,3 \\
\hline Wanita & 79 & 46,7 \\
\hline \multicolumn{3}{|l|}{ Usia } \\
\hline$<20$ thn & 18 & 10,7 \\
\hline $20-29$ thn & 29 & 17,2 \\
\hline $30-39$ thn & 34 & 20,1 \\
\hline $40-49$ thn & 72 & 42,6 \\
\hline 50-59 thn & 16 & 9,5 \\
\hline$>60$ thn & - & - \\
\hline \multicolumn{3}{|l|}{ Tingkat Pendidikan } \\
\hline SMU/Sederajat & 7 & 2,5 \\
\hline Diploma & 3 & 1,8 \\
\hline Sarjana (S1) & 110 & 65,1 \\
\hline Sarjana (S2-S3) & 49 & 29 \\
\hline \multicolumn{3}{|l|}{ Interest to come } \\
\hline Pleasure & 85 & 50,3 \\
\hline Bisnis & 36 & 21,3 \\
\hline Urusan Keluarga & 48 & 28,4 \\
\hline
\end{tabular}

Sumber: Output SPSS

Berdasarkan Tabel 1, dapat dilihat bahwa jenis kelamin responden pria lebih banyak $(53,3 \%)$ dibandingkan dengan responden wanita $(46,7 \%)$, dengan usia tertinggi pada golongan umur $40-49$ tahun $(42,6 \%)$ dan terendah golongan umur 50-59 tahun (9,5\%). Sedangkan pada tingkat pendidikan, banyak didominasi oleh Sarjana (S1) sebesar 65,1\%, diikuti oleh Sarjana (S2 \& S3) sebesar 29\%, Diploma 1,8\%, dan SMU/Sederajat 2,5\%. Tujuan para responden datang ke Provinsi Bangka Belitung lebih banyak dalam suasana liburan atau pleasure $(50,3 \%)$ diikuti oleh urusan keluarga $28,4 \%$, dan bisnis $21,3 \%$. Jumlah responden yang didapatkan melebihi dari ekspektasi peneliti, hal tersebut dikarenakan oleh adanya "Grasstrack exhibition" atau dapat disebut juga perlombaan balap motor yang memiliki ruang lingkup nasional. Sehingga tidak heran jika responden dari luar wilayah Provinsi Kepulauan Bangka Belitung didapatkan dengan jumlah yang melebihi ekspektasi peneliti dengan waktu yang telah ditentukan sebelumnya. 


\section{Hasil Confirmatory Factor Analysis (CFA)}

CFA digunakan untuk menilai kecocokan dari model pengukuran. Terdapat satu indikator pada variabel harga yang perlu dihilangkan karena memiliki nilai Standardized Regression Weights dibawah 0,5. Mayoritas indeks Goodness of Fit dalam penelitian ini menunjukkan bahwa model pengukuran sesuai dengan data ( $p$-value 0,402; RMSEA 0,014; AGFI 0,909; CFI 0,998; TLI 0,997; GFI 0,936). Nilai Average Variance Extracted (AVE) berada diatas nilai 0,5 , sehingga validitas diskriminan terpenuhi, sedangkan Construct Reliability (CR) berada di atas 0,7 , menunjukkan konsistensi internal yang memadai (Hair et al., 2014). Berdasarkan hasil uji signifikansi standardized loading estimate diperoleh informasi objektif bahwa semua indikator memberikan nilai standardized loading estimate yang signifikan $(p<0,05)$.

Tabel 2. Hasil CFA

\begin{tabular}{|c|c|c|c|}
\hline Item & Standardized Factor Loading & CR & AVE \\
\hline \multicolumn{4}{|l|}{ Suasana } \\
\hline Interior & 0,733 & \multirow{3}{*}{0,784} & \multirow{3}{*}{0,553} \\
\hline Peralatan & 0,614 & & \\
\hline Kenyamanan & 0,863 & & \\
\hline \multicolumn{4}{|l|}{ Kualitas Layanan } \\
\hline Kecepatan, & 0,858 & \multirow{4}{*}{0,870} & \multirow{4}{*}{0,631} \\
\hline Keramahan & 0,911 & & \\
\hline Keterampilan Komunikasi & 0,728 & & \\
\hline Profesionalisme & 0,653 & & \\
\hline \multicolumn{4}{|l|}{ Kualitas Makanan } \\
\hline Cita rasa & 0,820 & \multirow{3}{*}{0,866} & \multirow{3}{*}{0,683} \\
\hline Nutrisi & 0,785 & & \\
\hline Sanitasi & 0,873 & & \\
\hline \multicolumn{4}{|l|}{ Harga } \\
\hline Kesesuaian Harga, & 0,785 & \multirow{2}{*}{0,746} & \multirow{2}{*}{0,595} \\
\hline Perlakuan Harga & 0,758 & & \\
\hline \multicolumn{4}{|l|}{ Citra merek } \\
\hline Keterkenalan Merek, & 0,745 & \multirow{3}{*}{0,783} & \multirow{3}{*}{0,547} \\
\hline Brand Recognition & 0,740 & & \\
\hline Kesan Merek & 0,733 & & \\
\hline
\end{tabular}

Sumber: Output Amos

\section{Hasil Structural Equation Model (SEM)}

\section{Pengujian Hipotesis}

Indeks model fit menunjukkan bahwa model dapat diterima (Gambar 2). Statistik Chi-square bernilai 86,592 dengan 84 derajat kebebasan $(p=0,402, C \min / \mathrm{df}=1,031)$. Indikator lainnya menunjukkan bahwa model memiliki kecocokan yang baik untuk interpretasi lebih lanjut $(\mathrm{RMSEA}=0,014, \mathrm{RMR}=0,089, \mathrm{AGFI}=0,909, \mathrm{CFI}=0,998$, $\mathrm{GFI}=0,936$, dan TLI = 0997). Gambar 2 menunjukkan hasil hipotesis dan memberikan estimasi parameter. Hipotesis $\mathrm{H1}, \mathrm{H} 2, \mathrm{H} 3, \mathrm{H} \$, \mathrm{H} 5$, dan $\mathrm{H} 6$ mengusulkan hubungan struktural antara suasana, kualitas makanan, dan kualitas layanan berdasarkan harga dan citra merek. Studi ini menemukan bahwa harga dan citra merek yang dipersepsikan memiliki pengaruh positif., harga terhadap suasana $(H 1, \beta=0,201, p=0,018)$, harga terhadap kualitas makanan $(H 2, \beta=0,201, p=0,015)$, harga terhadap kualitas layanan $(H 3, \beta=0,818, p=0,000)$, citra merek terhadap suasana $(H 4, \beta=0,399, p=0,002)$, citra merek terhadap kualitas makanan $(H 5, \beta=0,319, p=$ $0,008)$, citra merek terhadap kualitas layanan $(H 6, \beta=0,027, p=0,552)$. Citra merek terhadap kualitas layanan memang memiliki pengaruh positif akan tetapi ternyata tidak signifikan. Dengan demikian, seluruh hipotesis yang diajukan berpengaruh positif. 


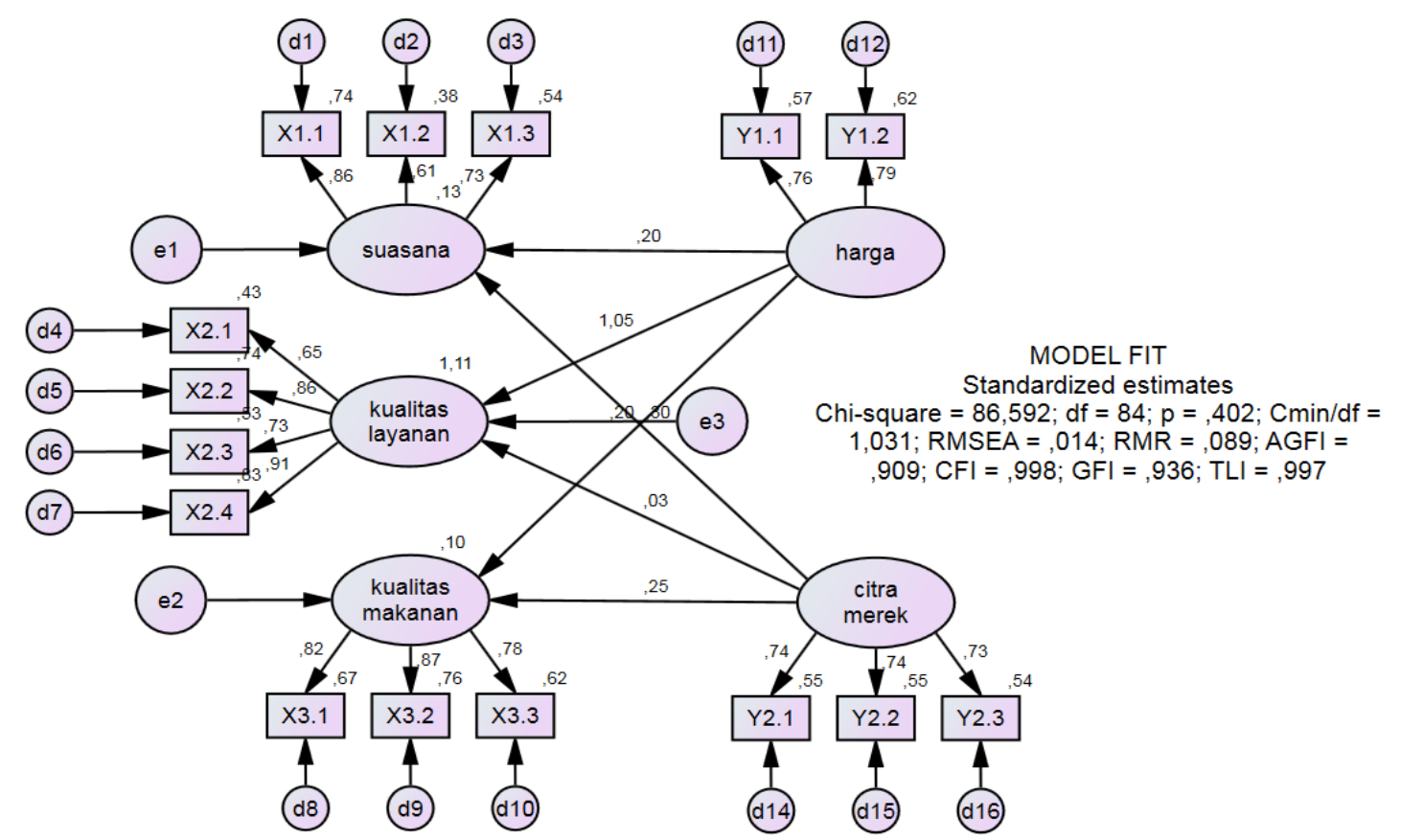

Gambar 2. Hasil Structural Equation Model (SEM)

\section{Pembahasan}

\section{Pengaruh Citra Merek Terhadap Atribut Pemilihan Restoran}

Tujuan utama dari studi ini adalah untuk menguji pengaruh citra merek dan harga terhadap atribut restoran yang digunakan konsumen dalam memilih restoran favorit mereka. Berdasarkan literatur sebelumnya, penelitian ini menguji latar belakang teoritis untuk preferensi atribut restoran konsumen sehubungan dengan harga dan citra merek. Hasil penelitian ini memberikan dukungan kuat untuk hubungan sebab akibat antara persepsi konsumen dan preferensi konsumen mengenai atribut kualitas restoran. Citra merek ditemukan sebagai faktor penting dalam preferensi atribut restoran konsumen. Temuan studi ini sebagian konsisten dengan penelitian Yi, Zhao, \& Joung pada tahun 2018, di mana mereka menyimpulkan bahwa citra merek memainkan peran penting dan positif dalam proses pengambilan keputusan konsumen restoran. Meskipun hasil kami mirip dengan Yi, Zhao, \& Joung (2018), penelitian kami menyertakan hasil yang berbeda, menunjukkan bahwa citra merek tidak mempengaruhi semua atribut kualitas restoran yakni kualitas layanan. Artinya, kualitas pelayanan memang memiliki hubungan yang positif terhadap citra merek yang dibangun oleh suatu restoran, akan tetapi belum tentu tingkat pelayanan sesuai dengan yang diinginkan oleh konsumen, dimana konsumen memiliki karakter dan persepsi yang berbeda dalam hal dilayani (Kim \& Jang, 2016).

\section{Pengaruh Harga Terhadap Atribut Pemilihan Restoran}

Selain daripada itu, harga memiliki peran yang cukup penting dalam menentukan atribut kualitas restoran dalam hal kesesuaian dan perlakuan harga (Tang, Repetti, \& Raab, 2019). Harga akan mempengaruhi preferensi konsumen restoran baik itu restoran biasa maupun mewah, dimana akan merefleksikan ekspektasi kualitas makanan, kualitas layanan, dan suasana terhadap restoran yang dituju. Hasil pada variabel harga studi ini bertentangan dengan hasil yang dikemukakan oleh Yi, Zhao, \& Joung (2018) dan Chiang \& Jang (2006), dimana mereka beranggapan bahwa harga memiliki pengaruh yang lemah terhadap atribut pemilihan kualitas restoran. Indikator kelengkapan pada harga dimenu ternyata tidak memberikan hasil yang baik untuk kesesuaian model, hal tersebut dapat diartikan bahwa konsumen tidak menjadikan prioritas harga-harga yang tertera pada menu, mereka berasumsi hanya pada kelas restoran yang dituju, mewah atau tidaknya. 


\section{Kesimpulan}

Hasil studi ini memberikan beberapa implikasi bahwa manajer restoran harus mengembangkan sistem kontrol kualitas restoran untuk terus memantau persepsi konsumen mengenai atribut kualitas restoran dan citra merek. Khususnya, manajer restoran harus memeriksa apakah suasana makan, kualitas makanan, dan tingkat kualitas layanan sejalan dengan konsep keseluruhan restoran dan target harapan konsumen untuk menciptakan citra merek yang positif. Dengan kata lain, ketika seorang konsumen melihat atau mendengar suatu merek, itu bukan hanya tentang logo restoran, tagline, atau iklan, melainkan memori dari pengalaman sebelumnya, rasa makanan, harga, suasana, dan layanan. Oleh karena itu, sistem informasi kontrol kualitas yang holistik diperlukan. Selain itu, tantangan utama bagi bisnis restoran adalah untuk membedakan diri dari pesaing dan membangun citra restoran yang lebih menarik daripada pesaing. Oleh karena itu, jika sebuah restoran bukan pemimpin market share, manajer restoran perlu mempertimbangkan strategi Blue Ocean Shift (Kim \& Mauborgne, 2017) untuk mengalahkan pesaing dan memaksimalkan nilai konsumen restoran. Dengan melakukan hal tersebut, restoran dapat membangun konsep uniknya sendiri dan mencerminkan citra mereknya sendiri.

Strategi yang baik dapat meningkatkan suasana makan, kualitas makanan, dan kualitas layanan serta dapat menambah nilai premium pada layanan atau produk restoran, yang secara langsung menghubungkan ke profitabilitas restoran dalam persaingan. Setiap konsumen memiliki kecenderungan yang berbeda berdasarkan pada tujuan mereka untuk mengunjungi restoran. Hasil penelitian ini menunjukkan bahwa suasana, kualitas makanan, dan kualitas layanan secara umum dipertimbangkan oleh konsumen sebagai faktor penting ketika memilih restoran karena hal tersebut dapat sangat mempengaruhi pengalaman makan konsumen dan secara langsung memengaruhi citra restoran. Misalnya, layanan yang kasar atau ceroboh dapat merusak pengalaman karena beberapa konsumen bahkan mungkin menganggap layanan yang buruk tersebut disengaja. Artinya, konsumen dapat menganggapnya sebagai penghinaan pribadi. Faktor layanan sebagai salahsatu variabel dalam studi ini dapat mencegah konsumen memilih restoran yang dituju. Serupa dengan harga yang ditawarkan, jika harga makanan terlalu mahal, maka akan memberikan ketidakpuasan dalam memilih restoran yang dituju. Untuk mempertahankan posisi pasar yang dominan, pemilik restoran perlu tetap mempertahankan atribut kualitas restoran yang selaras dengan konsep merek restoran, sehingga mendorong konsumen baru untuk memilih restoran mereka daripada pesaing.

\section{References}

Ali, A., Xiaoling, G., Sherwani, M., \& Ali, A. (2018). Antecedents of consumers' Halal brand purchase intention: an integrated approach. Management Decision, 56(4), 715-735.

Bowden-Everson, J. L. H., Dagger, T. S., \& Elliott, G. (2013). Engaging customers for loyalty in the restaurant industry: The role of satisfaction, trust, and delight. Journal of Foodservice Business Research, 16(1), 5275.

Bufquin, D., DiPietro, R., \& Partlow, C. (2017). The influence of the DinEX service quality dimensions on casualdining restaurant customers' satisfaction and behavioral intentions. Journal of foodservice business research, 20(5), 542-556.

Bruwer, J., \& Buller, C. (2012). Country-of-origin (COO) brand preferences and associated knowledge levels of Japanese wine consumers. Journal of Product \& Brand Management, 21(5), 307-316.

Cao, Y., \& Kim, K. (2015). How do customers perceive service quality in differently structured fast food restaurants?. Journal of Hospitality Marketing \& Management, 24(1), 99-117.

Chen, Y. C., Tsui, P. L., Chen, H. I., Tseng, H. L., \& Lee, C. S. (2019). A dining table without food: the floral experience at ethnic fine dining restaurants. British Food Journal.

Chiang, C. F., \& Jang, S. S. (2006). The effects of perceived price and brand image on value andpurchase intention: Leisure travelers' attitudes toward online hotel booking. Journal of Hospitality \& Leisure Marketing, 15(3), 49-69.

DeMicco, F. J. (2015). Cracker Barrel: A strategic case study in restaurant management. Journal of Foodservice Business Research, 18(4), 423-434. 
Ding, L., \& Chung, Y. (2014). Competitive Responses, Competitors' Strategic Orientations, and Imitated Strategy Types: Evidence from the US Restaurant Industry. International Journal of Tourism Sciences, 14(2), 18-35.

DiPietro, R. B., \& Levitt, J. (2019). Restaurant authenticity: factors that influence perception, satisfaction and return intentions at regional American-style restaurants. International Journal of Hospitality \& Tourism Administration, 20(1), 101-127.

Dutta, K., Parsa, H. G., Parsa, R. A., \& Bujisic, M. (2014). Change in consumer patronage and willingness to pay at different levels of service attributes in restaurants: A study in India. Journal of Quality Assurance in Hospitality \& Tourism, 15(2), 149-174.

Erkmen, E., \& Hancer, M. (2019). Building brand relationship for restaurants: An examination of other customers, brand image, trust, and restaurant attributes. International Journal of Contemporary Hospitality Management, 31(3), 1469-1487.

Espinosa, J. A., Ortinau, D. J., Krey, N., \& Monahan, L. (2018). l'll have the usual: how restaurant brand image, loyalty, and satisfaction keep customers coming back. Journal of Product \& Brand Management, 27(6), 599614.

Fan, A., Wu, L., \& Shen, H. (2019). The interaction effects of consumer susceptibility to interpersonal influence and type of word-of-mouth on Chinese consumers' restaurant choices. Journal of Foodservice Business Research, 1-14.

Hair, J. F., Black, W. C., Babin, B. J., \& Anderson, R. E. (2014). Multivariate data analysis: Pearson new international edition. Pearson Higher Ed.

Hyun, S. S., Han, H., \& Kim, W. (2016). A model of patrons' impulsive ordering behaviors in luxury restaurants. Asia Pacific Journal of Tourism Research, 21(5), 541-569.

Jalilvand, M. R., Pool, J. K., Nasrolahi Vosta, S., \& Kazemi, R. V. (2016). Antecedents and consequence of consumers' attitude towards brand preference: evidence from the restaurant industry. Anatolia, 27(2), 167176.

Jin, N., Lee, S., \& Huffman, L. (2012). Impact of restaurant experience on brand image and customer loyalty: Moderating role of dining motivation. Journal of Travel \& Tourism Marketing, 29(6), 532-551.

Jin, N., Line, N. D., \& Merkebu, J. (2016). The impact of brand prestige on trust, perceived risk, satisfaction, and loyalty in upscale restaurants. Journal of Hospitality Marketing \& Management, 25(5), 523-546.

Jongwanich, J., Park, D., \& Wongcharoen, P. (2019). Determinants of Producer Price versus Consumer price inflation in emerging Asia. Journal of the Asia Pacific Economy, 1-28.

Joung, H. W., Choi, E. K., \& Wang, E. (2016). Effects of perceived quality and perceived value of campus foodservice on customer satisfaction: Moderating role of gender. Journal of Quality Assurance in Hospitality \& Tourism, 17(2), 101-113.

Kim, J. H., \& Jang, S. (2016). Factors affecting memorability of service failures: A longitudinal analysis. International Journal of Contemporary Hospitality Management, 28(8), 1676-1701.

Kim, M. G., Lee, C. H., \& Mattila, A. S. (2014). Determinants of customer complaint behavior in a restaurant context: The role of culture, price level, and customer loyalty. Journal of Hospitality Marketing \& Management, 23(8), 885-906.

Kim, W. C., \& Mauborgne, R. (2017). Blue ocean shift: Beyond competing-proven steps to inspire confidence and seize new growth. Hachette UK.

Kim, Y. S., Raab, C., \& Bergman, C. (2010). Restaurant selection preferences of mature tourists in Las Vegas: A pilot study. International Journal of Hospitality \& Tourism Administration, 11(2), 157-170.

Kong, J. P., \& Mohd Jamil, S. (2014). Level of satisfaction among postgraduate health sciences students on the cafeteria facilities in Universiti Kebangsaan Malaysia, Kuala Lumpur Campus. International Journal of Quality and Service Sciences, 6(4), 258-273. 
Kotler, P., Armstrong, G., \& Opresnik, M. O. (2017). Principles of Marketing (17e Global). Harlow: Pearson Education Limited.

Kusumah, E. P. (2018). Customer Loyalty Model: Customer Satisfaction As Intervening Variable. Ecoforum Journal, $7(2)$.

Kusumah, E. P. (2019). Respon Konsumen Tentang Kualitas Pelayanan, Penerimaan Teknologi "Tracking System" dan Harga Pada Industri Jasa Pengiriman. Jurnal IImiah Bisnis Dan Ekonomi Asia, 13(2), 111-118.

López-Guzmán, T., \& Sánchez-Cañizares, S. (2012). Culinary tourism in Córdoba (Spain). British Food Journal.

Mak, A. H., Lumbers, M., Eves, A., \& Chang, R. C. (2012). Factors influencing tourist food consumption. International Journal of Hospitality Management, 31(3), 928-936.

McCall, M., \& Bruneau, C. L. (2010). Value, quality, and price knowledge as predictors of restaurant price sensitivity. Journal of Foodservice Business Research, 13(4), 304-310.

Miao, L., \& Mattila, A. S. (2013). Impulse buying in restaurant food consumption. Journal of foodservice business research, 16(5), 448-467.

Mohamed, M. E., Hewedi, M., Lehto, X., \& Maayouf, M. (2019). Marketing local food and cuisine culture online: a case study of DMO's websites in Egypt. International Journal of Tourism Cities.

Nemeschansky, B. (2019). Listen to your customer-how to manage your restaurant more effectively. Journal of Foodservice Business Research, 1-29.

Reich, A. Z. (2011). Relative perceived product quality: increasing the effectiveness of restaurant planning through a more effective integration of the competitive environment. Journal of foodservice business research, 14(1), 2-19.

Roseman, M. G., Mathe-Soulek, K., \& Krawczyk, M. (2017). The effect of psychological empowerment climate on restaurant food safety, food quality, and financial performance. Journal of Human Resources in Hospitality \& Tourism, 16(2), 137-152.

Tang, J., Repetti, T., \& Raab, C. (2019). Perceived fairness of revenue management practices in casual and finedining restaurants. Journal of Hospitality and Tourism Insights, 2(1), 92-108.

Vuong, B. N., \& Khanh Giao, H. N. (2019). The Impact of Perceived Brand Globalness on Consumers' Purchase Intention and the Moderating Role of Consumer Ethnocentrism: An Evidence from Vietnam. Journal of International Consumer Marketing, 1-22.

Wang, E. S. T. (2015). Effect of food service-brand equity on consumer-perceived food value, physical risk, and brand preference. British Food Journal, 117(2), 553-564.

Wu, H. C., \& Mohi, Z. (2015). Assessment of service quality in the fast-food restaurant. Journal of Foodservice Business Research, 18(4), 358-388.

Yi, S., Zhao, J., \& Joung, H. W. (2018). Influence of price and brand image on restaurant customers' restaurant selection attribute. Journal of foodservice business research, 21(2), 200-217. 